Article

\title{
Effect of Transaction Rules on Enterprise Transaction Costs Based on Williamson Transaction Cost Theory in Nanhai, China
}

\author{
Meie Deng $($ and Anlu Zhang * \\ College of Land Management, Huazhong Agricultural University, Wuhan 430070, China; \\ dengmeie0024@webmail.hzau.edu.cn \\ * Correspondence: zhanganlu@mail.hzau.edu.cn; Tel.: +86-1399-558-1694
}

Received: 11 December 2019; Accepted: 3 February 2020; Published: 5 February 2020

check for updates

\begin{abstract}
The high transaction costs due to the incomplete information and transaction rules of the rural collective construction land (RCCL) market indicate that the government must improve the rural collective construction land market. Transaction rules are an important means for the government to intervene in the market and promote the development of market order, to secure land tenure, and to improve the disclosure of information. Vertical integration may reduce enterprise transaction costs but will increase the governance cost of internal organizations in enterprises. Land commercialization and corporate governance restructuring is a considerable challenge worldwide. Using a field survey in Nanhai district, Guangdong province, China, we estimated how the transaction costs of the RCCL are influenced not only by three dimensions of transaction rules-openness, equity, and justice-but also by the human asset in EC or EJC. Tobit models were constructed, and the results show that (1) the greater number of collective leaders, the higher the enterprise transaction cost (human asset in EC or EJC increases transaction costs of enterprises) and (2) the transaction rules are not sufficiently open or fair, which leads to high costs of market information searching, opportunism, and corruption. The transaction information is not transparent and the lag in transaction supervision mode gives rise to unfair transactions, in which the formation mode of land price is unreasonable. Therefore, we suggest that the transaction rules of RCCL market should be further improved in the three dimensions of openness, equity, and justice. Chinese authorities should strengthen their current efforts to build a more open and fair market by reducing the transaction costs of enterprises and improving the transaction efficiency. Our work provides some insights into the improvement of market efficiency which will contribute to the development of the RCCL market in other areas of China and worldwide.
\end{abstract}

Keywords: rural collective construction land (RCCL); transaction costs; asset specificity; transaction uncertainty; transaction frequency; vertical integration; transaction rules

\section{Introduction}

Urban land commercialization began in late 1980s in China's eastern coastal area and was legalized nationally in early 1990s [1,2]. With the rapid development of urban land marketization and town and village enterprises (TVEs), the land, especially urban land became more and more scarce $[3,4]$. In order to meet demand of urban economic development and TVEs, the local government legally or illegally converted farmland at the rural-urban fringe or superior location to absorb the investment of foreign capital, China's Hong Kong, China's Taiwan, or joint venture [5-7]. The strategy of substitution of capital for land on one hand booms China's eastern coastal area, on the other hand gives rise to huge stock construction lands in rural and urban areas [8]. With the bankruptcy of TVEs, the rural collective construction land (RCCL) for rural collectives remained inactivated assets which cannot be lease or sale 
under the China's Land Management Law priori to 2019 [9]. According to China's Ministry of Nature Resources, the RCCL is $18,000,000 \mathrm{hm}^{2}$, while urban construction land is $7,000,000 \mathrm{hm}^{2}$ [4]. Unlike urban construction land, the RCCL located spatially fragmented and scattered, negotiation between urban developers and individual farmer households incur huge costs [3,5,6]. Moreover, transaction of the RCCL was legally forbidden. Facing huge RCCL and legal regulation, local governments either transfer implicitly or self-organize scattered farmer households horizontally [10].

The development of the implicit RCCL market between rural carders and urban developers encroached on farmers land interest and had negative impacts on land market order [11]. Since the 1990s, the Ministry of Land and Resources has launched a series of combating actions of implicit land markets $[12,13]$.

Self-organization of farmer households bottom up innovation creates land-based shareholding system in Nanhai District. Since 1992, farmer households integrated into shareholding cooperation according to labors, contractual farmland, and other agricultural assets [14,15]. Under the land-based shareholding system, the RCCL commercialization can be put into operation locally $[16,17]$. In 1999, the Ministry of Land and Resources selected Nanhai District in Guangdong Province, Wuhu City, Anhui Province as the pilots of RCCL transfer [13]. After six years RCCL marketization in demonstration areas, Guandong provincial government issued No. 100 document of the People's Government Administrative Measures for the Transfer of the Right to Use RCCL of Guangdong Province in 2005 [11]. Since then, the RCCL market has opened from illegally to legally at the province level [18]. Successful RCCL bottom-up marketization at the provincial level triggers the central government to up down institutional arrangement for national wide RCCL transaction [19,20]. Since 2008, the central government issues a series regulations on RCCL commercialization such as the Third Plenary Session of the 17th Central Committee of the Communist Party of China, The State-Owned Construction Land and the Rural Non-Agricultural Construction Land Have the Same Rights and Same Prices for the Same Location Land in 2008 [20,21], the Third Plenary Session of the 18th Central Committee of the Communist Party of China The RCCL Enter the Market with Equal Rights and Equity, and Establish a Unified Construction Land Market in Urban and Rural Areas in 2013 [6,7,22,23], the Deepen Reform Committee's 33 pilots of RCCL marketization in 2015. Four years later, openness, equality, and justice transaction rules were emphasized by the State Council Improvement of Construction Land Use Right Transfer and Conveyance on Secondary Market in 2019 [18].

As regards the openness of the RCCL transaction rules, it includes symmetry information of RCCL, enterprises, biding pattern, etc. [20,24]. Without fully informed plots, urban developers cannot bid a price to reflect the real value of RCCL [25-27]. If the land-based shareholding cooperative cannot access to the information of enterprises [28], the rural collective will face the risk of transaction default, which will lead to loss of RCCL transaction. The biding patterns includes open and implicit one. Compared with the implicit biding patterns, the open one for supplier and demander is fully informed, in which equal trading can be guaranteed $[29,30]$.

As for equity of the RCCL transaction rules, it consists of restriction on the transaction threshold, collection and return of transaction deposit, and the way of supervision [31-34]. Whether enterprises can access to the RCCL markets, it currently depends on fixed assets, scale and credit. Restriction on market access of enterprises will surely reduce competition, which will lower the price of the RCCL [31]. The enterprise should deposit a certain amount of money before participating in biding, it will reduce the risk of transaction default on one hand, on the other hand it will increase trading processes which lead to extra transaction costs. Market supervision including online and offline, government-led, and social media can achieve equal transaction but increase transaction costs [35,36].

Regarding justice, the RCCL transaction rules are composed of land pricing and service charges. Unlike urban land market, the RCCL lacks official base price stipulated by government, so the transaction of the RCCL faces uncertainty. To charge a service fee will increase the cost of enterprise $[37,38]$.

All of the above-mentioned three attributes (openness, equity, and justice) highly influence the RCCL market efficiency. However, few studies concentrate on the effects of transaction rules on 
enterprise transaction costs. This paper will construct a theoretical framework of the relationship between three attributes of transaction rules and transaction costs based on Williamson Transaction Cost Theory and take the earlier RCCL market in Nanhai as an example. The research will contribute to enrich the literature in this field and provide an experience for China's unified rural urban land market development and transition countries empirically.

The remainder of this paper is structured as follows: Section 2 proposes theoretical framework and hypothesis of transaction cost of RCCL market. Section 3 introduces the RCCL market in Nanhai District as a case study, data collection and methodology. Section 4 discusses empirical results. Section 5 concludes the effect of transaction rules on the transaction cost of enterprises and policy implications.

\section{Theoretical Framework and Hypotheses}

\subsection{Theoretical Framework}

As shown in Figure 1, transaction cost is the cost of using the economic system, emphasizing that transaction cost is caused by institutional friction, especially due to unclear property rights, which inevitably lead to many kinds of friction [39]. The market transaction rules for RCCL in Nanhai District, Guangdong province, China, have developed from bottom-up innovation to top-down arrangement in the RCCL pilots. The transition from no rules to informal rules to formal rules has considerably influenced the RCCL transaction cost. To meet the needs of industrialization and protect the rights and interests of the collective landowners, the farmers in Nanhai District have independently created a land-based shareholding system and interest distribution mode according to the proportion of shares.

Under informal rules and procedures, the transaction mode may be flexible and convenient which may save transaction costs. However, due to the lack of open, transparent, equal rules to guide land transfer and the lack of legal protection, farmers' land rights and interests cannot be protected, resulting in RCCL transfer chaos and low efficiency of land use $[14,18]$. So, the existence of hidden transaction default risk in RCCL leads to higher transaction costs. To rationally use land and normalize the order of land transfer, in 2005, Nanhai successively issued regulations of collective construction land transfer management. Under the local government regulations, RCCL began to enter the market formally from top to bottom, and the land transfer was generally orderly. The establishment of transaction rules reduces the uncertainty of the RCCL transaction environment, and the market is becoming increasingly open, fair, and just. In the process of land transfer, land information and transaction procedures are more open and transparent. Due to the short time when the RCCL market has been opened to public, the incompleteness of the market transaction rules including the formation of land price, income distribution, and market supervision lead to the high costs of market transactions.

According to Williamson's transaction cost theory, the transaction generates transaction costs in the market. A good transaction system will reduce the transaction costs of both the suppliers and the demanders. The transaction costs incurring in the transaction process include the cost of information searching, contract signing, and effective supervision and transaction notarization. The theory of transaction cost mainly includes three dimensions: asset specificity, uncertainty and transaction frequency. Asset specificity mainly includes human asset, material asset and geographical location. Transaction cost theory pays more attention to the cost of asset specificity, due to the more specific, the less possibility to be used for other purposes, the higher transaction cost. Transaction uncertainty mainly refers to the uncertainty of transaction environment. The uncertainty of transaction system has a serious impact on transaction costs, resulting in the stronger uncertainty and the higher transaction cost. For example, information symmetry affects the costs of information searching and the costs of transaction negotiation. More transactions times and stronger the transaction frequency will lead to higher transaction costs of the suppliers and the demanders [40-42]. 


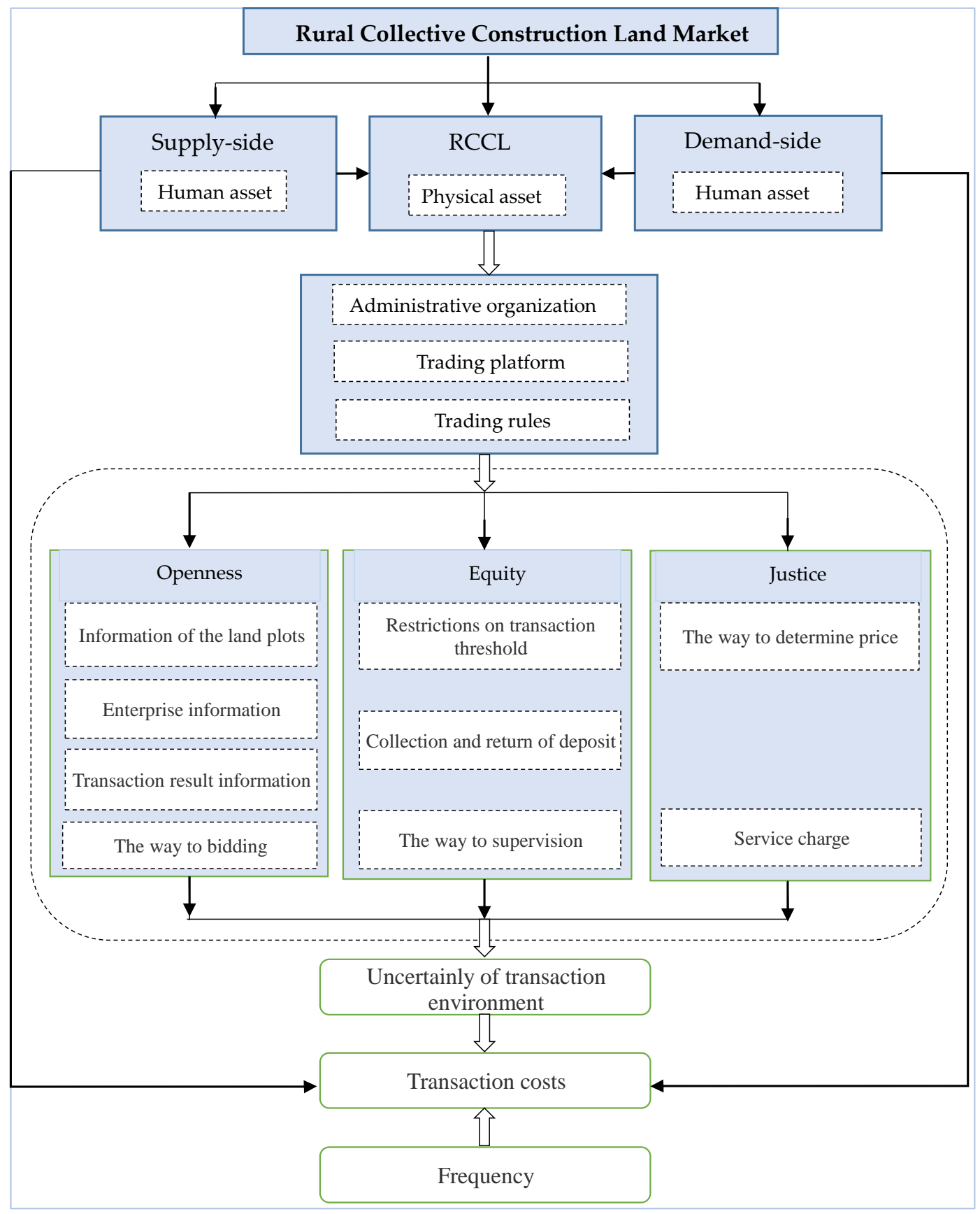

Figure 1. The theoretical framework.

In this context, the RCCL transaction rules in Nanhai are becoming increasingly necessary. To avoid rent-seeking and opportunism behaviors, the local government of Nanhai District pays more attention to the openness, equity, and justice of the trading rules. The openness transaction rules mainly include the degree of land information disclosure and participants' information, transaction results, and the method of bidding. The equity transaction rules mainly include the restrictions on transaction threshold, collection and return of transaction deposit, and the method of supervision. The justice transaction rules mainly include how price and service charges are determined. As land transfer information on various trading platforms differs at the village, town, or district level, the costs of information searching differ. For example, the information is more public at the district level than the village level, so the cost of information searching for enterprises will be lower. The bidding method 
can be either explicit or implicit bidding. The explicit bidding is the more open of the two. In the past, no clear requirements on the transaction threshold have been stated, but in formal transactions, rules impose strict threshold restrictions for enterprises applying for land transaction. Excessive restrictions increase the unfairness of the market and increase the possibility of collusion between the government and enterprises, thereby increasing transaction costs. The payment and the specific rules of the return are unclear, which is not fair to the enterprises on the demand side of the RCCL market because the deposit payment and the time of the return affect the transaction cost for enterprises. The supervision method directly affects the equity in the RCCL market. In the past, the implicit transfer of RCCL lacked market supervision, the transfers were chaotic, and the risk cost of default was very high. The greater the supervision; the fairer the transaction; the less possible the government, enterprises, and collective economic organizations collude; and the lower the transaction cost. The form of land price is directly related to the transaction cost of the demander. The price of land transfer has mainly been based on oral negotiation, which lacks a contractual basis and fairness. Compared with the informal rules in the past, the transaction rules are fairer to land pricing. However, the lack of detailed regulations on the formation, detection, guidance, supervision, and price declaration of the land price has resulted in unfair transaction prices. The fairer the land price, the more reasonable the land value, and the lower the transaction cost. The service payment is directly related to the transaction cost.

Given the short period of the market and the incompleteness of market transaction rules, the RCCL market environment still faces many uncertainties, which also leads to high market transaction costs. To reduce transaction costs, enterprises and rural collective economic organizations (economic cooperatives and economic joint communities) tend to choose vertical integration governance instead of market transaction. For example, Baisha village (Dali, Nanhai District, Guangdong Province) transferred 79,000 $\mathrm{m}^{2}$ of collective construction land in 2015. Guangdong Liying Real Estate Co., Ltd. (Foshan city, China) (See Figure 2) built a total construction area of $800,000 \mathrm{~m}^{2}$, with an investment of about 5 billion yuan, and built a business center (Xinggang Cheng). The Sheraton Hotel covers an area of about $12,000 \mathrm{~m}^{2}$ with a building area of about $30,000 \mathrm{~m}^{2}$ in the Xinggang Cheng business center. The Sheraton Hotel was built by the village collective and the enterprise, and the vertical integration model was used to replace the market transaction [43,44]. On the RCCL market supply side and demand side, buyers and sellers communicate with each other in transactions. Therefore, we wanted to determine if the human asset of RSCs have an impact on the transaction cost of the enterprise, and if so, if it affects the cost of market transactions.

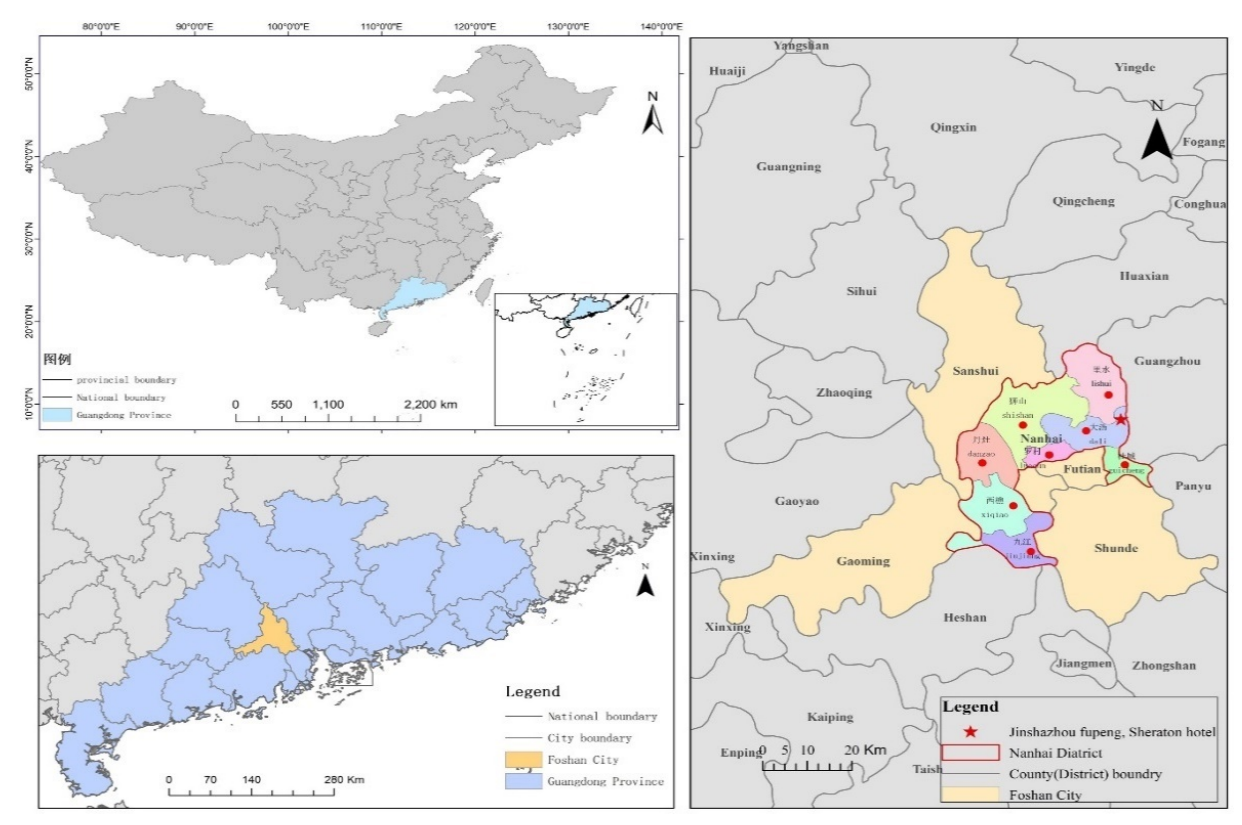

Figure 2. The location of Nanhai district, Guangdong, China. 


\subsection{Hypothesis}

Williamson [39] stated that the factors affecting the market transaction costs can be divided into two groups. The first group is transaction factors, which refer to market uncertainty, the number of potential counterparts, and the technical structure of transactions (refers to the technical characteristics of trading goods, including the degree of asset specificity, trading frequency, etc.). The second group is human factors, including bound rationality and opportunism. William noted that opportunistic behavior, market uncertainty, limited negotiation, and asset specificity increase the transaction cost of the market. The transaction cost of the enterprises includes capital specificity. Assets have three characteristics-specificity of assets, specificity of asset location, and the specificity of human assets. Human asset includes two parts-the human asset of EC or EJC and the human asset of enterprise.

The human asset is an important part of market transaction cost. The RCCL market supply side and demand side, buyer and seller negotiate with each other in transactions. Theoretically, a higher scale of EC or EJC will reduce negotiation costs of the enterprises other things being equal. However, EC or EJC in China are not only economic organizations but also political ones, and basic grass root governance unite. When EC or EJC horizontally integrate, the political organization and local governance will surely increase at the same time [3]. Whether the human asset specificity of EC or EJC will change the transaction costs of the enterprises depends on the negotiation saved and political organization costs and local grass-roots governance increased. Therefore, we hypothesized that

Hypothesis 1 (H1). The degree of human assets of EC or EJC may change the transaction costs of enterprises.

Enterprises participate in the market transaction process from transaction voting to contract signing; the RCCL transaction rules applicable in these transaction procedures mainly include transaction voting by shareholders, government approval, entry on transaction platform, approval by traders of the platform, information disclosure, transaction, notarization, land registration, and implementation of contract. Whether the information of land transaction is more open, whether restrictions are on market transaction, the cost of collection and return of transaction deposit, whether the supervision and punishment are fair, and whether the methods of pricing and service charge are reasonable all seriously affect the transaction costs of enterprises. As such, we proposed that

Hypothesis 2 (H2). The degree of openness, equity and justice of transaction rules can reduce transaction costs.

\section{Study Area, Data, and Methodology}

\subsection{Study Area}

Nanhai District $\left(22^{\circ} 48^{\prime} 03^{\prime \prime}-23^{\circ} 18^{\prime} 00^{\prime \prime} \mathrm{N}, 112^{\circ} 51^{\prime} 55^{\prime \prime}-113^{\circ} 15^{\prime} 47^{\prime \prime} \mathrm{E}\right)$ is located in Foshan City, Guangdong province, adjacent to Hong Kong. The study area is composed of seven townships and 274 villages. It covers $1073.82 \mathrm{~km}^{2}$, of which $536.93 \mathrm{~km}^{2}$ is construction land. We chose Nanhai District as our study area as itis the first land shareholding system incorporating typical market-oriented RCCL transaction. In the early 1990s, the collective construction land began to implicit trade spontaneously. In 2005, Nanhai District successively issued the local regulations for collective construction land transfer management. Under the local government's regulations, the RCCL began to officially enter the market from top to bottom, and the land transfer tended to be orderly. In 2010, the town and village level collective asset trading platforms were established. Since then, the village-level transaction platform was officially established; land with a transaction amount of less than 250,000 yuan must be traded on the village-level transaction platform, and the land transfer system is becoming increasingly normalized. In 2011, the administrative measures for the transfer (lease) of the right to use RCCL in Nanhai District, Foshan city further normalize the RCCL market. In 2014, the town (street) trading 
center officially became the trading platform of the RCCL in Nanhai District. In 2015, a parcel of land was officially traded in the district level trading center.

\subsection{Data Collection}

We conducted an empirical study basing on the data collected from seven villages in Nanhai District, Guangdong in 2018. The villages include Guicheng, Dali, Shishan, Danzao, Xiqiao, Jiujiang, and Lishui. The survey respondents were enterprise personnel and leaders, and the rural collective shareholders were responsible for RCCL transactions. In order to test the hypotheses, we designed the questionnaire with the following five sections. The first part was related to the basic information of the respondents, such as age, education level, income level, etc. The second part was the costs of the enterprise under the rules of transaction. The third part was concerned with the three dimensions of the openness, equity, and justice. The fourth part requested transaction frequency information. The fifth part was the cognition and suggestion of the current situation of RCCL market. We obtained 380 questionnaires, of which 350 were valid. Other socioeconomic data on collectives and enterprises came from the yearbooks.

\subsection{Variables}

Based on our hypotheses, transaction cost is the dependent variable, and the degree of openness, equity, and justice of the RCCL market are independent variables. The specificity of human assets includes two factors-the human asset of EC or EJC and the human asset of enterprise. The human asset of enterprise includes the level of education and the specific professional skills of the transaction negotiators organized by the enterprises. The stronger the human asset, the higher the transaction costs. Human assets of EC or EJC includes the number of persons on the board of directors, the number of collective leaders, and the number of villager's shareholders. The higher the number of people on the board, collective leaders, and villager shareholders, the greater the impact on the market transaction cost.

The other control variables are asset specificity and transaction frequency. The following indicators were designed based on transaction cost theory [40-42] (as shown in Table 1):

(1) Physical assets include capital invested by enterprises and annual output value. The more capital an enterprise invests, the higher the risk. If default occurs due to imperfect market trading rules, the more capital the enterprise invests, the greater the risk. Faced with the risk of transaction default, the larger the annual output value, the greater the transaction cost.

(2) Geographical location includes plot scale and parcel location attribute. The size of trading land parcels and the shape of land impact transaction costs. If the construction land is developed for other purposes, the value decreases, thus resulting in high transaction costs. Location can be characterized as the distance from the traded land parcel to the town center. The closer to the town center, the higher the value of construction land.

(3) Uncertainty of transaction environment is composed of openness, equity, and justice characteristics of the RCCL market transaction rules. To prevent other variables from interfering with the results, the influencing factors such as existence of a land use certificate, property ownership certificate, payment of land use tax, and payment of factory rent tax were added as the control variables.

(4) The openness of transaction rules includes (1) the degree of disclosure of information about the plot, (2) the degree of disclosure of information about the enterprise, (3) the degree of disclosure of information about the land transaction results, and (4) the method to bidding. The more information is available about the land transfer and the land transaction result, the lower the cost of information searching. The more information available about the enterprise, the lower the enterprise cost of organizing the negotiation. Explicit bidding is more open than implicit bidding, which can reasonably affect the value of the land. 
(5) The equity of transaction rules includes (1) restrictions on transaction threshold, (2) collection and return of transaction deposit, and (3) supervision method. The higher the restrictions on the RCCL entering the market and the more the government intervention, the greater the loss of free competition in the market. The larger the land transaction cash deposit, the higher transaction cost. If more methods of supervision are used, the lower the opportunism and rent-seeking behavior.

(6) The justice of transaction rules is composed of (1) how price is determined (2) and service charges. Compared with negotiating, RCCL transactions through bidding may be more open and fairer, which can reduce the uncertainty of the transaction environment and the transaction costs. If higher service fees are collected, the higher the cost of the enterprise.

(7) Transaction frequency is calculated as 50 (the longest industrial land use rights lease available) divided by the actual contract term in the RCCL market. If the trading rules are imperfect multiple transactions will occur, so negotiation and organization costs increase with transaction frequency.

Table 1. The definition of variables and description of statistics.

\begin{tabular}{|c|c|c|c|c|}
\hline Variables & & & Definition & Mean \\
\hline \multirow{9}{*}{ Asset specificity } & \multirow{5}{*}{ Human asset } & Education level $\left(X_{1}\right)$ & $\begin{array}{c}\text { Primary school }=1, \text { junior high } \\
\text { school }=2, \text { senior high school }=3, \\
\text { University }=4, \text { postgraduate }=5, \\
\text { doctor }=6\end{array}$ & 5.20 \\
\hline & & $\begin{array}{l}\text { Specific professional skills } \\
\qquad\left(X_{2}\right)\end{array}$ & yes $=1$, no $=0$ & 0.45 \\
\hline & & Board size $\left(X_{3}\right)$ & the number of persons of board & 51.02 \\
\hline & & $\begin{array}{c}\text { The level of Board of } \\
\text { directors' governance }\left(X_{4}\right)\end{array}$ & the number of collective leaders & 3.30 \\
\hline & & $\begin{array}{l}\text { The level of Board of } \\
\text { directors' governance }\left(X_{5}\right)\end{array}$ & $\begin{array}{c}\text { the number of villager's } \\
\text { shareholders }\end{array}$ & 2.01 \\
\hline & \multirow{2}{*}{ Physical asset } & $\begin{array}{l}\text { Invested capital of the } \\
\text { enterprise }\left(X_{6}\right)\end{array}$ & the actual value $\left(10^{4} \mathrm{RMB}\right)$ & 1100.22 \\
\hline & & Annual output value $\left(X_{7}\right)$ & the actual value $\left(10^{4} \mathrm{RMB}\right)$ & $22,085.05$ \\
\hline & \multirow{2}{*}{$\begin{array}{l}\text { Geographical } \\
\text { location }\end{array}$} & Plot scale $\left(X_{8}\right)$ & the actual value $\left(\mathrm{m}^{2}\right)$ & $31,002.73$ \\
\hline & & $\begin{array}{l}\text { Parcel location attribute } \\
\qquad\left(X_{9}\right)\end{array}$ & $\begin{array}{l}\text { distance from the land traded to } \\
\text { the town Centre }(\mathrm{km})\end{array}$ & 8.11 \\
\hline \multirow{7}{*}{$\begin{array}{l}\text { Transaction } \\
\text { uncertainty }\end{array}$} & \multirow{4}{*}{ Openness } & $\begin{array}{l}\text { Degree of disclosure of } \\
\text { information about plot } \\
\qquad\left(X_{10}\right)\end{array}$ & $\begin{array}{c}\text { village level }=1 \text {, town level }=2, \\
\text { district level }=3, \text { national } \\
\text { standardized }=4, \text { information } \\
\text { platform }=5\end{array}$ & 4.07 \\
\hline & & $\begin{array}{l}\text { Degree of disclosure of } \\
\text { information about } \\
\text { enterprise }\left(X_{11}\right)\end{array}$ & $\begin{array}{c}\text { village level }=1 \text {, town level }=2 \text {, } \\
\text { district level }=3 \text {, national } \\
\text { standardized }=4 \text {, information } \\
\text { platform }=5\end{array}$ & 3.96 \\
\hline & & $\begin{array}{l}\text { Degree of disclosure of } \\
\text { information about results } \\
\qquad\left(X_{12}\right)\end{array}$ & $\begin{array}{c}\text { village level }=1 \text {, town level }=2, \\
\text { district level }=3, \text { national } \\
\text { standardized }=4, \text { information } \\
\text { platform }=5\end{array}$ & 3.02 \\
\hline & & The way to bidding $\left(X_{13}\right)$ & $\begin{aligned} \text { Explicit bidding } & =1, \text { implicit } \\
\text { bidding } & =0\end{aligned}$ & 0.40 \\
\hline & \multirow[b]{3}{*}{ Equity } & $\begin{array}{l}\text { The restrictions on } \\
\text { transaction threshold }\left(X_{14}\right)\end{array}$ & yes $=1$, no $=0$ & 0.38 \\
\hline & & $\begin{array}{l}\text { Collection and return of } \\
\text { transaction deposit }\left(X_{15}\right)\end{array}$ & $\begin{array}{c}\geq 20 \%=1,10-19 \%=1,5-9 \%=3 \\
\leq 4 \%=4\end{array}$ & 3.92 \\
\hline & & $\begin{array}{l}\text { The way of supervision } \\
\qquad\left(X_{16}\right)\end{array}$ & $\begin{array}{l}\text { no supervision }=1 \text {, platform } \\
\text { internal supervision }=2, \\
\text { government's participation in } \\
\text { platform supervision, offline }=3, \\
\text { government, villagers and the } \\
\text { public's participation in platform } \\
\text { supervision, online }=4\end{array}$ & 2.53 \\
\hline
\end{tabular}


Table 1. Cont.

\begin{tabular}{|c|c|c|c|c|}
\hline Variables & & & Definition & Mean \\
\hline & Justice & $\begin{array}{c}\text { The way to determine } \\
\text { price }\left(X_{17}\right)\end{array}$ & $\begin{array}{c}\text { government evaluation }=1 \text {, } \\
\text { third-party intermediary } \\
\text { evaluation }=2, \text { government and } \\
\text { third-party intermediary together } \\
=3 \text {, third party, villagers' } \\
\text { representatives and enterprises } \\
\text { participate }=4\end{array}$ & 2.22 \\
\hline & & $\begin{array}{l}\text { Service charge }\left(10^{2} \mathrm{RMB}\right) \\
\left(\mathrm{X}_{18}\right)\end{array}$ & $1=\leq 1,2=2-3,3=4-5,4=\geq 6$ & 2.74 \\
\hline $\begin{array}{l}\text { Transaction } \\
\text { frequency }\end{array}$ & & $\begin{array}{c}\text { Transaction frequency } \\
\left(X_{19}\right)\end{array}$ & $50 /$ years of the contract & 5.49 \\
\hline \multirow{4}{*}{ Controlled variable } & & $\begin{array}{l}\text { Whether have the Land } \\
\text { Use Certificate }\left(X_{20}\right)\end{array}$ & yes $=1$, no $=0$ & 0.30 \\
\hline & & $\begin{array}{c}\text { Whether have the Property } \\
\text { Ownership Certificate } \\
\left(X_{21}\right)\end{array}$ & yes $=1$, no $=0$ & 0.42 \\
\hline & & $\begin{array}{c}\text { Whether have payed land } \\
\text { use tax }\left(X_{22}\right)\end{array}$ & yes $=1$, no $=0$ & 0.61 \\
\hline & & $\begin{array}{l}\text { Whether have payed } \\
\text { factory rent tax }\left(X_{23}\right)\end{array}$ & yes $=1$, no $=0$ & 0.75 \\
\hline
\end{tabular}

\subsection{Methods}

\subsubsection{Estimation of Transaction Costs}

In the RCCL market, the transaction process includes the following steps: transaction voting by shareholders, government approval, entry on transaction platform, approval by traders of the platform, information disclosure, transaction, notarization, land registration, implementation of contract. The total transaction costs can be calculated as [35,36]

$$
C_{\text {total }}=\sum_{i=1}^{n} \text { Labor }_{i} \times \text { Time }_{i} \times 68.64+\text { Cash }_{i}
$$

where $C_{\text {total }}$ is the total transaction cost (yuan), Labor $_{i}$ is the number of people involved in stage I, Time is the days spent on the trading stage $i ; 68.64$ is daily salary (yuan/day), and Cash $_{i}$ is the direct expense in step $i$ (yuan).

\subsubsection{Tobit Model}

As the transaction costs are all above zero, the limited dependent variable model (Tobit) should be adopted when the independent variable is truncated or censored. This model is used to analyze consequent numeric variables, as well as virtual variables using the maximum likelihood estimation method. Tobit model is constructed as (Tobin, 1958)

$$
\mathrm{Y}=\left\{\begin{array}{c}
\beta^{T} X_{j}+\varepsilon_{j}, \beta^{T} X_{j}+\varepsilon_{j}>0 \\
0, \text { otherwise }
\end{array}\right.
$$

where $\mathrm{Y}$ is the independent variable, $\mathrm{Xj}$ is the independent variables, $\beta$ is the parameter to be estimated, $\varepsilon_{j}$ is the stochastic disturbance term, and $\xi_{j} \sim \mathrm{N}\left(0, \sigma^{2}\right)$. 


\section{Results}

\subsection{Transaction Rosts}

According to Equation (2), the total transaction costs can be measured by the sum of costs in each stage of the transaction process, which include the labor costs, time costs, and cash. According to the Price Bureau in Foshan (the upper administrative unit in Nankai), the lowest standard for a monthly salary is 1510 yuan/month (\$223.18 USD), meaning the daily salary is 68.64 yuan/day, which can be used to calculate the labor costs and time costs. The average transaction cost organized by enterprise is about 50,000 yuan.

\subsection{Tobit Model Results}

The results of Tobit regression models are listed in Table 2. The factors influencing capital specificity on transaction cost mainly include education level, the number of collective leaders, capital invested by enterprises, and plot scale. Education level has a negative impact on the RCCL market transaction cost — that is, the higher level of the education, the lower costs of negotiation. The number of collective leaders positively impacts the cost of the RCCL transaction market, in Model 1 and in Model 2. The number of collective leaders in EJC are more than the number in EC, which indicates that enterprises need to spend more time and more expenses to negotiate with village collective leaders in EJC. Compared with EC, human assets in EJC increased transaction costs of enterprises. The stronger the specificity of human asset, the higher the transaction cost. The capital invested by the enterprise positively impacts the cost of the RCCL transaction market, that is, the higher the investment capital of enterprises, the higher the market risk. The plot scale has a significantly positive impact on the cost of the RCCL transaction market, that is, the larger the area of land transaction, the higher the costs to be paid by the enterprise. Therefore, the results confirm Hypothesis 1.

Table 2. The results of the Tobit model.

\begin{tabular}{|c|c|c|c|}
\hline & Variable & $\begin{array}{c}\text { Economic Cooperative } \\
\text { (Jingjishe) } \\
\text { Model } 1\end{array}$ & $\begin{array}{l}\text { Economic Joint } \\
\text { Community } \\
\text { (Jinglianshe) } \\
\text { Model } 2\end{array}$ \\
\hline \multirow{2}{*}{$\begin{array}{l}\text { Human asset of } \\
\text { enterprises }\end{array}$} & Education level $\left(X_{1}\right)$ & $-0.1121^{* *}$ & $-0.1257^{* *}$ \\
\hline & Specific professional skills $\left(X_{2}\right)$ & 0.0092 & 0.0423 \\
\hline \multirow{3}{*}{$\begin{array}{l}\text { Human asset of EC or } \\
\text { EJC }\end{array}$} & Board size $\left(X_{3}\right)$ & 1.2025 & 1.3672 \\
\hline & $\begin{array}{l}\text { the level of Board of directors' } \\
\text { governance }\left(X_{4}\right)\end{array}$ & $0.2980 *$ & $0.8557^{* * *}$ \\
\hline & $\begin{array}{l}\text { the level of Board of directors' } \\
\text { governance }\left(X_{5}\right)\end{array}$ & 0.3077 & 0.2691 \\
\hline \multirow{2}{*}{$\begin{array}{l}\text { Physical } \\
\text { asset }\end{array}$} & $\begin{array}{l}\text { Invested capital of the enterprises } \\
\qquad\left(X_{6}\right)\end{array}$ & $0.5599 * * *$ & $0.4208^{* *}$ \\
\hline & annual output value $\left(X_{7}\right)$ & -0.6011 & -0.6822 \\
\hline \multirow{2}{*}{ Geographical location } & plot scale $\left(X_{8}\right)$ & $0.5022 * *$ & $0.4886^{* *}$ \\
\hline & Parcel location attribute $\left(X_{9}\right)$ & 0.1146 & 0.1153 \\
\hline \multirow{4}{*}{ Openness } & $\begin{array}{c}\text { degree of disclosure of information } \\
\text { about land plots }\left(X_{10}\right)\end{array}$ & $-1.2018^{* * *}$ & $-0.9944 * *$ \\
\hline & $\begin{array}{c}\text { degree of disclosure of information } \\
\text { about enterprise }\left(X_{11}\right)\end{array}$ & $-0.8650^{* * *}$ & $-0.7995^{* *}$ \\
\hline & $\begin{array}{l}\text { degree of disclosure of information } \\
\text { about results }\left(X_{12}\right)\end{array}$ & -0.1972 & -0.1778 \\
\hline & the way to bidding $\left(X_{13}\right)$ & 0.0561 & 0.0144 \\
\hline
\end{tabular}


Table 2. Cont.

\begin{tabular}{|c|c|c|c|}
\hline & Variable & $\begin{array}{c}\text { Economic Cooperative } \\
\text { (Jingjishe) } \\
\text { Model } 1\end{array}$ & $\begin{array}{l}\text { Economic Joint } \\
\text { Community } \\
\text { (Jinglianshe) } \\
\text { Model } 2\end{array}$ \\
\hline \multirow{3}{*}{ Equity } & $\begin{array}{l}\text { the restrictions on transaction } \\
\text { threshold }\left(X_{14}\right)\end{array}$ & 0.1626 & 0.1250 \\
\hline & $\begin{array}{c}\text { Collection and return of transaction } \\
\text { deposit }\left(X_{15}\right)\end{array}$ & $0.2923^{* * *}$ & $0.1989^{*}$ \\
\hline & The way of supervision $\left(X_{16}\right)$ & $-1.7949^{* * *}$ & $-1.5501 * *$ \\
\hline \multirow{2}{*}{ Justice } & the way to determine price $\left(X_{17}\right)$ & $-0.9612 * *$ & $-0.8802 * *$ \\
\hline & service charge $\left(X_{18}\right)$ & $0.0620 * *$ & 0.0450 \\
\hline transaction frequency & transaction frequency $\left(X_{19}\right)$ & 0.1300 & 0.1139 \\
\hline \multirow{4}{*}{ controlled variable } & $\begin{array}{l}\text { Whether have the Land Use } \\
\text { Certificate }\left(X_{20}\right)\end{array}$ & $-0.1911^{* * *}$ & $-0.1880^{* * *}$ \\
\hline & $\begin{array}{l}\text { Whether have the Property } \\
\text { Ownership Certificate }\left(X_{21}\right)\end{array}$ & -0.1750 & -0.1551 \\
\hline & $\begin{array}{l}\text { Whether have payed land use tax } \\
\qquad\left(X_{22}\right)\end{array}$ & $-0.0869^{* *}$ & $-0.0799 *$ \\
\hline & $\begin{array}{l}\text { Whether have payed factory rent tax } \\
\left(X_{23}\right)\end{array}$ & 0.021 & 0.1190 \\
\hline constant & & 2.1023 * & $5.4533 * * *$ \\
\hline
\end{tabular}

* Significant correlations at the 0.10 level $\left(p<0.10\right.$, both sides); ${ }^{* *}$ significant correlations at the 0.05 level $(p<0.05$, both sides); ${ }^{* * *}$ significant correlation at the 0.01 level $(p<0.01$, both sides).

The factors influencing transaction uncertainty (Table 3) mainly include information disclosure degree about plot and about the enterprise, collection and return of transaction deposit, transaction supervision method, method of determining price, and service charges. From the perspective of the openness of the RCCL market trading rules, information disclosure degree about a plot has a significantly negative impact on the transaction cost of the RCCL market. The transaction cost decreased by $1.261 \%$ for each $1 \%$ increase in information disclosure degree about the plot. The more open the plot information, the lower the cost of information search. The information disclosure degree about the enterprise has a negative impact on the RCCL market transaction cost-for every $1 \%$ increase in the information disclosure degree about the enterprise, the transaction cost decreases by $0.875 \%$. The more open the information, the lower the cost of bargaining. From the perspective of the equity of the transaction rules of the RCCL market, collection and return of transaction deposit has a significantly positive impact on transaction cost of RCCL market. The larger the amount of deposit, the higher the transaction cost of the enterprise. Supervision method negatively impacts the RCCL market transaction costs. For every $1 \%$ increase in supervision methods, transaction costs decrease by $1.795 \%$. The greater the supervision, the lower the cost of corruption, thus reducing and preventing transaction risk, protecting the interests of the transaction subject, and reducing the transaction costs of the enterprise. From the perspective of justice of transaction rules of the RCCL market, the method of pricing negatively and significantly impacts RCCL market transaction costs. For each $1 \%$ increase in justice of land price formation, transaction cost decreases by $0.965 \%$. The RCCL is owned by the village collective, so the RCCL transfer price must allow the collective economic organization and the villagers to participate in voting and decision-making, and the price must be evaluated by a third-party intermediary agency. The fairer the land price, the less the opportunism and rent-seeking behavior, and the lower the transaction costs. Service charge significantly positively impacts the transaction cost of RCCL market. When an enterprise pays higher fees, the transaction cost increases $[45,46]$. Therefore, the openness, equity, and justice of the RCCL market transaction rules directly affect the market transaction environment, reducing the uncertainty of the institutionalized environment and lowering the enterprise cost in the transaction market. The results accept Hypothesis 2. 
Table 3. The results of the Tobit model.

\begin{tabular}{|c|c|c|c|c|c|}
\hline Dependent & Independent & Coef & Std. Err & $\mathbf{t}$ & $p>t$ \\
\hline \multirow{5}{*}{ Human asset } & Education level $\left(X_{1}\right)$ & $-0.096^{* * *}$ & 0.013 & -2.89 & 0.009 \\
\hline & Specific professional skills $\left(X_{2}\right)$ & 0.015 & 0.012 & 1.17 & 0.233 \\
\hline & Board size $\left(X_{3}\right)$ & 0.014 & 0.011 & 1.25 & 0.204 \\
\hline & the level of Board of directors' governance $\left(X_{4}\right)$ & -0.027 & 0.001 & -1.83 & 0.151 \\
\hline & the level of Board of directors' governance $\left(X_{5}\right)$ & -0.036 & 0.014 & -0.91 & 0.212 \\
\hline \multirow{2}{*}{ Physical asset } & Invested capital of the enterprise $\left(X_{6}\right)$ & $0.569 * * *$ & 0.215 & 2.53 & 0.006 \\
\hline & annual output value $\left(X_{7}\right)$ & -0.601 & 0.027 & -0.79 & 0.562 \\
\hline \multirow{2}{*}{ Geographical location } & plot scale $\left(X_{8}\right)$ & $0.502 * *$ & 0.206 & 2.92 & 0.045 \\
\hline & Parcel location attribute $\left(X_{9}\right)$ & 0.114 & 0.045 & 0.46 & 0.280 \\
\hline \multirow{4}{*}{ Openness } & degree of disclosure of information about plot $\left(X_{10}\right)$ & $-1.261^{* * *}$ & 0.108 & -2.33 & 0.002 \\
\hline & $\begin{array}{c}\text { degree of disclosure of information about } \\
\text { enterprise }\left(X_{11}\right)\end{array}$ & $-0.875^{* * *}$ & 0.016 & -2.66 & 0.009 \\
\hline & $\begin{array}{l}\text { degree of disclosure of information about results } \\
\qquad\left(X_{12}\right)\end{array}$ & -0.197 & 0.123 & -1.31 & 0.901 \\
\hline & the way to bidding $\left(X_{13}\right)$ & 0.052 & 0.002 & 1.05 & 0.531 \\
\hline \multirow{3}{*}{ Equity } & the restrictions on transaction threshold $\left(X_{14}\right)$ & 0.166 & 0.014 & 1.12 & 0.190 \\
\hline & Collection and return of transaction deposit $\left(X_{15}\right)$ & $0.290 * * *$ & 0.006 & 2.64 & 0.011 \\
\hline & the way of supervision $\left(X_{16}\right)$ & $-1.795^{* * *}$ & 0.018 & -2.87 & 0.005 \\
\hline \multirow{2}{*}{ Justice } & the way to determine price $\left(X_{17}\right)$ & $-0.965^{* *}$ & 0.021 & -2.21 & 0.042 \\
\hline & service charge $\left(X_{18}\right)$ & $0.073^{* *}$ & 0.011 & 2.95 & 0.036 \\
\hline Transaction frequency & transaction frequency $\left(X_{19}\right)$ & 0.132 & 0.004 & 1.59 & 0.205 \\
\hline \multirow{9}{*}{ Controlled variable } & Whether have the Land Use Certificate $\left(X_{20}\right)$ & $-0.192 * * *$ & 0.015 & -3.12 & 0.007 \\
\hline & $\begin{array}{l}\text { Whether have the Property Ownership Certificate } \\
\qquad\left(X_{21}\right)\end{array}$ & -0.176 & 0.012 & -0.97 & 0.235 \\
\hline & Whether have payed land use tax $\left(X_{22}\right)$ & $-0.087^{* *}$ & 0.004 & -2.12 & 0.041 \\
\hline & Whether have payed factory rent tax $\left(X_{23}\right)$ & 0.021 & 0.010 & 1.36 & 0.309 \\
\hline & constant & $0.102 * *$ & 0.041 & 2.58 & 0.016 \\
\hline & Log likelihood $=$ & 326.221 & & & \\
\hline & Pseudo $\mathrm{R}^{2}=$ & 0.0625 & & & \\
\hline & LR chi2 $(23)=$ & 59.80 & & & \\
\hline & Prob $>$ chi $2=$ & 0. 000 & & & \\
\hline
\end{tabular}

* Significant correlations at the 0.10 level $(p<0.10$, both sides $) ;{ }^{* *}$ significant correlations at the 0.05 level $(p<0.05$, both sides); ${ }^{* * *}$ significant correlation at the 0.01 level $(p<0.01$, both sides).

Among the other control variables, the possession of a land use certificate and paying land use tax has a significantly negative impact on the RCCL market transaction cost. Having a land use certificate can reduce the uncertainty about the RCCL market environment and prevent the occurrence of transaction disputes and risks, which reduce the transaction cost of the enterprise. Paying land use tax can avoid the time costs, such as disputes and breach of contract, caused by the failure to handle tax.

\section{Conclusions and Discussion}

\subsection{Conclusions}

Based on Williamson's transaction cost theory, we analyzed the effect of transaction rules on the transaction cost of enterprises in the rural collective construction land market.

First, with increasing asset specificity, the transaction costs increase. The main factors influencing the asset specificity are education level, the number of collective leaders, the investment capital of the enterprise, and plot scale. Therefore, the stronger the asset specificity of market transactions, the higher the enterprise transaction cost. The greater number of collective leaders, the higher the enterprise transaction cost. Compared with EC, the enterprises need to spend more time and more expenses to negotiate with collective leaders in EJC, so the transaction costs of human asset were increased for enterprises.

Second, higher uncertainty of the rules in the three dimensions of openness, equity, and justice leads to higher transaction costs. Due to the strong uncertainty in market transactions, enterprises tend to choose vertical integration governance instead of market transactions to reduce transaction costs. 
The uncertainties in market transactions are mainly affected by the dubious political rules. Through the Xinggang Cheng case study, we found the government must improve the openness, equity, and justice of the RCCL market transaction rules that reduce the uncertainty of the market transaction environment reduces the transaction costs of the enterprise. From the perspective of the openness of transaction rules, the transparency should be increased to reduce the cost of information searching. From the perspective of equity of transaction rules, the collection and return of transaction deposit can reduce the transaction costs of the enterprise. The government should enhance supervision for preventing corruption and illegal collusion between collective economic organizations and enterprises. From the perspective of justice of transaction rules, the method to determine price must be objective and fair, and the land price should be reasonable that reflect the land value. Villagers and collective economic organizations must participate in the voting on land price. Service charges directly affect the transaction cost of the enterprise. When the transaction rules of RCCL market are more open, equity and justice reduce the uncertainty of the transaction environment, and then the enterprises abandon vertical integration in favor of a more perfect market transaction.

\subsection{Policy Implications}

In order to improve the efficiency of market transaction, making open, fair and just transaction rules which can protect the safety of both sides of transaction, and save transaction costs, and improve business efficiency. Using the Nanhai mode, the openness, equity, and justice rules of RCCL market transaction should be established to protect the rights security of enterprises when entering the market. The use of perfect market transaction rules can avoid opportunism and rent-seeking behavior as well as corruption to better protect the interests of enterprises and reduce enterprise transaction costs. In addition, human asset in EC or EJC increases the transaction costs of the enterprise. The government and collective economic organization should increase the supervision to the collective leadership behavior.

First, the RCCL market trading rules, improve the transparency of information in the trading platform and establish a national standardized information disclosure platform. Second, the government should strengthen and expand methods of supervision. The public and enterprises should also participate in supervision. Third, a scientific and reasonable method of deciding land price should be formulated that requires third-party intermediary agencies to evaluate land price and collective economic organizations and villagers' representatives and the government to participate in voting to ensure the fairness and orderliness of transaction and reduce the risk of transaction environment, and reduce enterprise transaction costs.

\subsection{Discussion}

First, we construct a theoretical framework of relationship between the transaction rules and the RCCL transaction costs based on Williamson Transaction Cost Theory. According to Williamson's Transaction Cost Theory, the transaction costs are influenced by three attributes-assets specificity, uncertainty and frequency, we pay much attention to uncertainty associated with three attributes of China's current transaction rules (openness, equity, and justice) besides of Williamson's three dimensions. Actually, the openness, equity, and justice are vital to China's RCCL market efficiency. The variables to define the three attributes may select the substitutes in the future.

Second, we try to estimate the RCCL transaction costs dealing with immeasurable of transaction costs on one hand and quantify the relationship between enterprises transaction costs and uncertainty associated with transaction rules on the other hand. The measurement of transaction costs we have done is based on the transaction process and labor and the time spend. How to precisely measure the transaction costs and decompose the transaction costs from production costs need to be further studied.

Third, the transaction costs of RCCL market and the transaction rules mainly base on Williamson Transaction Theory. Besides assets specificity, uncertainty, and frequency, land tenure and titling will 
have impacts on transaction costs. The assumption of secure land tenure and complete registration in the study is not always the case.

Author Contributions: Conceptualization, M.D. and A.Z.; methodology, A.Z.; validation, M.D.; formal analysis, M.D. and A.Z.; investigation, M.D.; data collection, M.D.; writing—original draft preparation, M.D. and A.Z.; writing - review and editing, M.D. All authors have read and agreed to the published version of the manuscript.

Funding: This research was funded by the Major Project of Philosophy and Social Sciences, Chinese Ministry of Education (14JZD009), the Major Project of National Social Science Foundation of China (18ZDA054), and the National Natural Science Foundation of China (71873053, 71573101, 71804054, and 71704061).

Conflicts of Interest: The authors declare that they have no conflict of interest. This research complies with all laws of the People's Republic of China, where it was performed. This article does not contain any studies performed by any of the authors with human participants or animals. The funders had no role in the design of the study; in the collection, analyses, or interpretation of data; in the writing of the manuscript, or in the decision to publish the results.

\section{References}

1. Long, H. Land consolidation: An indispensable way of spatial restructuring in rural China. J. Geog. Sci. 2014, 24, 211-225. [CrossRef]

2. Long, H.L.; Li, Y.R.; Liu, Y.S.; Woods, M.; Zou, J. Accelerated restructuring in rural China fueled by "increasing vs. decreasing balance" land-use policy for dealing with hollowed villages. Land Use Policy 2012, 29, 11-22. [CrossRef]

3. Cui, Z. Partial Intimations of the Coming Whole: The Chongqing Experiment in Light of the Theories of Henry George, James Meade, and Antonio Gramsci. Modern China 2011, 37, 646-660. [CrossRef]

4. Huang, K.; Zhang, A.L. Market Integration Mechanism of Urban and Rural Construction Land. Reform 2016, 2,69-79. (In Chinese)

5. Obeng-Odoom, F. Property in the Commons: Origins and Paradigms. Rev. Radic. Political Econ. 2016, 48, 9-19. [CrossRef]

6. Gürel, B. Semi-private Landownership and Capitalist Agriculture in Contemporary China. Rev. Radic. Political Econ. 2019. [CrossRef]

7. Obeng-Odoom, F.; Stilwell, F. Security of tenure in international development discourse. Int. Dev. Plan. Rev. 2013, 35, 315-333. [CrossRef]

8. Yep, R. Filling the institutional void in rural land markets in southern China: Is there room for spontaneous change from below? Dev. Chang. 2015, 46, 534-561. [CrossRef]

9. Long, H.; Zou, J.; Liu, Y. Differentiation of rural development driven by industrialization and urbanization in eastern coastal China. Habitat Int. 2009, 33, 454-462. [CrossRef]

10. Xie, X.X.; Zhang, A.L.; Wen, L.J.; Bin, P. How horizontal integration affects transaction costs of rural collective construction land market? An empirical analysis in Nanhai District, Guangdong Province, China. Land Use Policy 2019, 82, 138-146. [CrossRef]

11. Wen, L.J.; Zhang, A.L.; Chen, Z.; Yang, X.; Wang, H. Evaluation of the Land Development Rights and Protection of the Rural Collective Construction Land Assets-Based on a Choice Experiments of Suppliers and Demanders in Land Market. J. Agrotech. Econ. 2019, 4, 29-42. [CrossRef]

12. Wen, L.J.; Zhang, A.L. Relationship among Institutional Innovation of Land Coupon, Market Mechanism of Land Development Right and Fulfillment of Rural Land Assets Value. China Land Sci. 2016, 30, 33-40. [CrossRef]

13. Wen, L.J.; Zhang, A.L. Comparative Analysis of Rural Land Market Development in Yangtze River Delta and Pearl River Delta Regions: Based on the Empirical Analysis from Songjiang, Jinshan, Nanhai and Dongguan. China Land Sci. 2016, 30, 64-71. [CrossRef]

14. Zhang, T.; Zhang, A.L.; Deng, S.L. Transaction costs research of collective construction land market based on Williamson analysis paradigm: An empirical analysis of 1872 market transaction data and 372 questionnaire data in Nanhai District, Guangdong Province. China Land Sci. 2017, 31, 11-21. (In Chinese) 
15. Zhang, T.; Zhang, A.L.; Deng, S.L.; Hu, Y. Econometric research on the development of rural collective construction land market and its impact factors: An empirical analysis based on 1872 market transaction data and 398 questionnaire data in Nanhai District, Guangdong Province. China Land Sci. 2016, 30, $22-31$. (In Chinese)

16. Mearns, R. Access to Land in Rural India; Policy Research Working Paper 2123; World Bank: Washington, DC, USA, 1999.

17. Liu, S.; Carter, M.R.; Yao, Y. Dimensions and diversity of property rights in rural China: Dilemmas on the road to further reform. World Dev. 1998, 26, 1789-1806. [CrossRef]

18. Deng, M.E.; Zhang, A.L.; Chen, H.B. Analysis on Transaction Cost of Supply and Demand Sides under the Rules of Collective Owned Construction Land Use Right Transfer. J. Henan Agric. Univ. 2018, 52, $294-299$. (In Chinese)

19. Long, H.; Heilig, G.K.; Li, X.B.; Zhang, M. Socio-economic development and land use change: Analysis of rural housing land transition in the Transect of the Yangtze River, China. Land Use Policy 2007, 24, 141-153. [CrossRef]

20. General Office of the State Council of China (GOSC). Management Measures for Cross-Provincial Adjustment of Savings Indicators Linked to Increase and Decrease of Urban and Rural Construction Land; General Office of the State Council: Beijing, China. Available online: http://www.gov.cn/zhengce/content/2018-03/26/content_ 5277477.htm (accessed on 26 March 2018).

21. Ministry of Land and Resources (MLR), National Development and Reform Commission (NDRC) of China, National Land Consolidation Plan (2016-2020). Available online: http://www.mlr.gov.cn/zwgk/zytz/201702/ t20170215_1440315.htm (accessed on 1 January 2017).

22. Ministry of Land and Resources of China (MLR). Land Consolidation Terms (TD/T1054-2018); Ministry of Land and Resources of China: Beijing, China, 2018.

23. The Ministry of Land and Resources (MLR). Opinions on Supporting Poverty Alleviation in Deep Poverty-Stricken Areas. Available online: http://www.mlr.gov.cn/zwgk/zytz/201712/t20171227_1712503.htm (accessed on 6 December 2017).

24. Banerjee, A.V.; Gertler, P.J.; Ghatak, M. Empowerment and Efficiency: Tenancy Reform in West Bengal. J. Political Econ. 2002, 110, 239-280. [CrossRef]

25. Bittner, C.; Sofer, M. Land use changes in the rural-urban fringe: An Israeli case study. Land Use Policy 2013, 33, 11-19. [CrossRef]

26. Deininger, K.; Jin, S. The potential of land rental markets in the process of economic development: Evidence from China. J. Dev. Econ. 2005, 78, 241-270. [CrossRef]

27. Krusekopf, C.C. Diversity in land tenure arrangements under the household responsibility system in China. China Econ. Rev. 2002, 13, 297-312. [CrossRef]

28. Yi, R.; Yang, B.; Tao, H. Characterizing the land shareholding cooperative: A case study of Shanglin village in Jiangsu, China. Sustainability 2017, 9, 1175.

29. Deininger, K.; May, J. Can There be Growth with Equity: An initial assessment of Land Reform in South Africa. Policy Res. Working Paper Series 2000, 1-32. [CrossRef]

30. Deininger, K.; Olinto, P. Asset distribution, inequality, and growth. Policy Res. Work. Pap. 2000, 93, 1091-1113. [CrossRef]

31. Deininger, K.; Jin, S.Q.; Nagarajan, H.K. Efficiency and Equity Impacts of Rural Land Rental Restrictions: Evidence from India. Eur. Econ. Rev. 2008, 52, 892-918. [CrossRef]

32. Carter, M.R.; Zimmerman, F. The Dynamic Cost and Persistence of Asset Inequality in an Agrarian Economy. J. Dev. Econ. 2000, 63, 265-302. [CrossRef]

33. Bardhan, P.; Bowles, S.; Gintis, H. Wealth inequality, wealth constraints and economic performance. Handb. Income Distrib. 2000, 1, 541-603. [CrossRef]

34. Shagaida, N. Agricultural land market in Russia: Living with constraints. Comp. Econ. Stud. 2005, 47, 127-140. [CrossRef]

35. Deininger, K.; Hoogeveen, H.; Kinsey, B.H. Economic Benefits and Costs of Land Redistribution in Zimbabwe in the Early 1980s. World Dev. 2004, 32, 1697-1709. [CrossRef]

36. Holden, S.T.; Otsuka, K.; Place, F. The Emergence of Land Markets in Africa: Impacts on Poverty, Equity, and Efficiency; Resources for the Future: Washington, DC, USA, 2009.

37. Yao, Y. The Development of the Land Lease Market in Rural China. Land Econ. 2000, 76, 252-266. [CrossRef] 
38. Walker, G.; Weber, D. A transaction cost approach to make-or-buy decisions. Adm. Sci. Q. 1984, $29,373-391$. [CrossRef]

39. Williamson, O.; Jeffrey, H. Understanding the Employment Relation: The Analysis of Idiosyncratic Exchange. Bell J. Econ. 1977, 6, 250-280. [CrossRef]

40. Williamson, O. Markets and Hierarchies: Analysis and Antitrust Implications; Free Press: New York, NY, USA, 1975.

41. Williamson, O. The New Institutional Economics: Taking Stock, Looking Ahead. J. Econ. Lit. 2000, 38, 595-613. [CrossRef]

42. Williamson, O. Credible Commitments: Using Hostages to Support Exchange. Am. Econ. Rev. 1983, 73, 519-540.

43. Waterman, D.; Weiss, A.A. The effects of vertical integration between cable television systems and pay cable networks. J. Econom. 1996, 72, 357-395. [CrossRef]

44. Hart, O.; Tirole, J.; Carlton, D.W.; Williamson, O.E. Vertical integration and market foreclosure. Working Pap. 1990, 205-286. [CrossRef]

45. Li, J.; Ning, X.; Sun, J.; Xiong, X. Simulating the Barriers of Transaction Costs to Public Rental Housing Exits: The Case of Wuhan, China. Sustainability 2018, 10, 1549. [CrossRef]

46. Avery, W.; Wang, Y.; Lee, S.H. The Effect of Cross-Border E-Commerce on China's International Trade: An Empirical Study Based on Transaction Cost Analysis. Sustainability 2017, 9, 2028. [CrossRef]

(C) 2020 by the authors. Licensee MDPI, Basel, Switzerland. This article is an open access article distributed under the terms and conditions of the Creative Commons Attribution (CC BY) license (http://creativecommons.org/licenses/by/4.0/). 